\title{
Economics of Milk Production in Belagavi District of Karnataka: A Comparative Study on Women Dairy Self-Help Group Members and Non-members
}

\author{
Makarabbi, G." and A.K. Chauhan \\ Division of Dairy Economics, Statistics and Management, ICAR-NDRI, Karnal -132001, India \\ *Corresponding author: makarabbigb600@gmail.com
}

\begin{abstract}
The present investigation was conducted in the Belagavi district of Karnataka to compare the economics of milk production with member and non-members of Women Dairy Self-Help Groups (WDSHGs). The primary data was collected from 90 members and 90 non-members of households from two seasons i.e. rainy and summer in the year 2015-16. The gross cost for maintaining local cow, crossbred cow and buffalo was found to be ₹ 91.75, ₹ 146.22 and ₹ 128.29 for member is more as against ₹ 88.11 for local cow, ₹ 142.36 for crossbred cow and ₹ 124.67 for buffalo in case of non-members. The cost per litre of milk of local cow (₹ 28.15), crossbred cow (₹ 20.73) and buffalo (₹ 26.82) was found to be slightly less for members in comparison to non-members ₹ 28.91 for local cow, ₹ 21.10 for crossbred cow and ₹ 27.08 for buffalo. The net returns per liter of milk was found to be ₹-1.74 for local cow, ₹ 3.76 for crossbred cow and ₹ 2.45 for buffalo in members were slightly higher as compared to ₹ -2.57 for local cow, ₹ 3.18 for crossbred cow and ₹ 2.02 for buffalo in non-members. Here, net return per liter of milk for local cow is negative because, less productivity of local cow overall the net returns from dairy farming is higher for members as compared to non-members.
\end{abstract}

Keywords: Women Dairy Self Help Groups, Poverty, Milk production, Belagavi, Karnataka

Microfinance through SHG has become a ladder for the poor to bring them up not only economically but also socially, mentally and attitudinally. A Self-Help Group is a small economically homogenous and affinity of group of rural poor voluntarily formed to save and mutually agree to contribute to a common fund to be lent to its members as per group decision for their socio-economic development (NABARD). These SHGs were helpful to the members to access credit with absence of collateral securities and guarantor (Firoze, S.M. 2011). SHGs can establish a relationship between the formal financial institutions and the poor for providing credit and other banking facilities (Devi, G. 2014). This borrowed credit will be utilized for several dairy activities e.g. purchasing animals, green fodder, dry fodder, concentrates and others. Groups also help to income generating activities and empowerment of members through group dynamics.
During 1986-87 Mysore Resettlement and Development Agency (MYRADA) is the first informal group lending in India, this was supported and funded by National Bank for Agriculture and Rural Development (NABARD) as an Action Research Project. In 1992, NABARD launched a pilot project linking 500 SHGs with banking systems across the country. Now, SHG-Bank linkage programme in India has grown to the developing world's largest microfinance programme for the rural poor. It comprising around 7.4 million SHGs with a total of 97 million members received finance, among this $90 \%$ of them were formed and managed by women (NABARD Report, 2014-15). Few studies were conducted on economics of financing to SelfHelp Groups members and non-members (Devi, 2010) reported that the net cost per litre of milk of local cow, crossbred cow and buffalo was found to be less for members as compared with non- 
member. Another study on economic analysis of dairy co-operatives (Kumari, 2015) reported that net returns per litre of milk were higher for members as compared to non-members. Also, found that feed cost is the major component of total cost. In view of this, the paper was attempted to analyze the how cost and returns of milk production for members and non-members of Women Dairy Self Help Groups (WDSHGs).

\section{Data and Methodology}

The Belagavi district was selected purposively to analyse the economics of milk production by members and non-members of WDSHGs. Three talukas viz., Gokak, Athani and Chikkodi were selected purposively based on highest number of SHGs. From each taluka five villages were selected purposively based on presence of Women Dairy Self Help Groups. Then, two WDSHGs from each village and three members from each WDSHG were randomly selected. Then, total of 90 members and 90 non-members of similar socio-economic status were selected. Later which were post stratified into small (1-3 milch animals), medium (4 \& 5 milch animals) and large (6 and above milch animals) by using cumulative square root frequency method.

Primary data was collected from member and nonmembers households on various aspects of milk production by using personal interview schedule. The collected data were scrutinized, tabulated and subjected to tabular analysis. The following methodology was adopted to analyse the cost of milk production.

Fixed cost: Fixed cost includes interest on fixed capital and depreciation on animals, cattle sheds and machinery. The interest on fixed capital was worked out at the prevailing rate of interest i.e. at $9.60 \%$ per annum. Depreciation on fixed capital was worked out separately for milch animals, cattle shed, machinery and equipments. The fixed cost was apportioned on the basis of Standard Animal Units (SAUs). Depreciation on milch animals was worked out as follows:

- Local cows - 10\% (productive life 10 years)

- CB Cows - 8\% (productive life 12.5 years)

- Buffaloes - $10 \%$ (productive life 10 years)

Depreciation rates for cattle shed, chaff cutter, milk cans and other equipment applied as under

\begin{tabular}{cc}
\hline Particulars & Depreciation per year (in \%) \\
\hline Pucca building & 2 \\
Semi- Pucca building & 5 \\
Water trough & 10 \\
Chaff cutter & 10 \\
Milk can & 20 \\
Buckets & 20 \\
\hline
\end{tabular}

For instance fixed assets are jointly used for cattle of all age groups and either sex. For the apportionment of such joint expenses on per animal basis, the total cattle herd in the dairy farm, comprising of adult and young male and female animals has been converted into cattle equivalent following Standard Animal Units or SAUs suggested by Sirohi et al. (2015) in Table 1.

Table 1: Standard Animal Units for southern region (SAU/animal)

\begin{tabular}{cccc}
\hline Animals & $\begin{array}{c}\text { Local } \\
\text { Cow }\end{array}$ & $\begin{array}{c}\text { Crossbred } \\
\text { cow }\end{array}$ & Buffalo \\
\hline Adult male ( $\geq 3$ years) & 0.97 & 1.12 & 1.04 \\
Adult female ( $\geq 3$ years) & 1.00 & 1.62 & 1.24 \\
Young stock male ( $<1$ year) & 0.22 & 0.24 & 0.24 \\
Young stock female ( $<1$ year) & 0.27 & 0.3 & 0.28 \\
Young stock male $(>1$ year $)$ & 0.54 & 0.63 & 0.6 \\
Young stock female $(>1$ year) & 0.47 & 0.52 & 0.51 \\
Heifer & 0.82 & 0.86 & 0.77 \\
\hline
\end{tabular}

Source: Sirohi et al. (2015).

Variable costs: Variable costs are those costs which are incurred on the variable factors of production and can be altered in the short run. It includes feed cost, labour cost, and miscellaneous cost. The variable expenses on fodder, feed and labour were collected for individual milch animals.

Feed and fodder cost: The cost incurred on green fodder, dry fodder and concentrates were worked out by multiplying quantities of feeds and fodder consumed by animals with respective prevailing price in the study area.

Labor cost: It included cost of family as well as paid labour (hired labour). The cost of hired labour was calculated considering type of work allotted and wages paid whereas, family labour costs were determined on the basis of existing wage rate of permanent farm labour.

Miscellaneous Cost: Miscellaneous cost included the cost of breeding by Artificial Inspection (AI) or 
natural service, cost of vaccination and medicines, cost of repair, electricity, water charges, detergents etc. They were calculated on the basis of per milch animal per day for different types of milch animal as well as per S.A.U for joint expenditure. Interest on working capital was not calculated as there is regular flow of income from sale of milk to the producer.

1. Gross cost: It was obtained by adding all the cost components including fixed and variable costs, i.e.,

Gross Cost $=$ Total Variable Cost + Total Fixed Cost

2. Net Cost: The net cost was worked out by deducting the imputed value of dung, from the gross cost, i.e.,

Net Cost $=$ Gross Cost - Value of Dung

3. Gross returns: Gross returns were obtained by multiplying milk yield of an individual milch animal with respective prevailing prices in the study area.

Gross returns $=$ Quantity of milk $\times$ Market price of milk

4. Net returns: Net return was calculated by subtracting net cost from gross returns

Net returns $=$ Gross returns - Net cost

5. Cost of Milk Production: All the costs were calculated for per animal per day. This also indicates the cost of maintaining an animal per day.

\section{RESULTS AND DISCUSSION}

\section{Feeding pattern}

The average quantity of feed and fodder fed to local cow, crossbred cow and buffalo was shown in the Table 2.

Table 2: Average intake of feed and fodder fed to the animals by member and non-member group in different herd size category $(\mathrm{Kg} /$ animal/day)

\begin{tabular}{cccc}
\hline \multirow{2}{*}{$\begin{array}{c}\text { Feed and } \\
\text { fodder }\end{array}$} & Type of animal & \multicolumn{2}{c}{ Overall } \\
\cline { 3 - 4 } & Local cow & 10.33 & $\begin{array}{c}\text { Non- } \\
\text { member }\end{array}$ \\
\hline \multirow{2}{*}{ Green fodder } & Crossbred cow & 16.51 & 16.32 \\
& Buffalo & 14.24 & 13.88
\end{tabular}

\begin{tabular}{cccc} 
& Local cow & 4.57 & 4.60 \\
Dry fodder & Crossbred cow & 2.74 & 2.64 \\
& Buffalo & 4.92 & 4.88 \\
& Local cow & 0.79 & 0.73 \\
Concentrates & Crossbred cow & 2.22 & 2.15 \\
& Buffalo & 1.57 & 1.51 \\
\hline
\end{tabular}

The quantity of green fodder for crossbred animal was fed more as compared with local cow and buffalo in both member and non-member case. Also, the average quantity of concentrates was fed to crossbred cow was more followed by buffalo and local cow. Because of the milk productivity of the crossbred cow was more as compared to buffalo and local cow.

\section{Maintenance cost and returns from local milch cow}

The maintenance cost local cow was presented in the Table 2. The per day average gross cost for maintaining local was found to be more for members (₹ 91.75) as compared to non-members (₹ 88.11). The overall variable cost was $78.35 \%$ and fixed cost was $21.65 \%$ in members. While the $77.42 \%$ and $22.58 \%$ in non-member case. The feed and fodder cost was accounted $64.84 \%$ as followed by labor cost $24.56 \%$ and miscellaneous cost $10.36 \%$ in total variable cost for members. Corresponding figures for nonmembers were $67.32 \%, 24.41 \%$ and $7.50 \%$ for feed and fodder, labour cost and miscellaneous cost, respectively. The overall per litre cost of milk was found to be slightly lesser for members (₹ 28.15) as compared to non-members ( $₹ 28.91$ ). The net returns from the local cow were found to be negative in both member and non-member. It may due to low productivity of local cows.

Table 3: Average cost and return of local cow for member and non-member groups across different herd size categories ( $₹$ /animal/day)

\begin{tabular}{ccc}
\hline \multirow{2}{*}{ Cost/Return component } & \multicolumn{2}{c}{ Overall } \\
& Member & Non-member \\
Green Fodder (F1) & $15.37(32.94)$ & $15.76(34.24)$ \\
Dry Fodder (F2) & $17.25(36.97)$ & $16.86(36.63)$ \\
Concentrate (F3) & $14.03(30.08)$ & $13.41(29.13)$ \\
Feed \& Fodder cost & $46.65(64.84)$ & $46.04(67.32)$ \\
(V1=F1+F2+F3+G) & $17.86(24.56)$ & $17.28(24.41)$ \\
Labor Cost (V2) & $7.43(10.36)$ & $5.07(7.50)$ \\
Miscellaneous Cost (V3)
\end{tabular}




\begin{tabular}{ccc}
$\begin{array}{c}\text { Total Variable Cost } \\
\text { (TVC=V1+V2+V3) }\end{array}$ & $71.94(78.35)$ & $68.39(77.42)$ \\
Total Fixed Cost (TFC) & $19.81(21.65)$ & $19.72(22.58)$ \\
Gross cost (A=TFC+TVC) & $91.75(100.00)$ & $88.11(100.00)$ \\
Value of Dung (B) & 3.39 & 3.25 \\
Net cost (C=A-B) & 88.36 & 84.86 \\
Price of Milk & 26.41 & 26.34 \\
Average milk production/ & 3.16 & 2.94 \\
Animal/Day(E) & & \\
Gross Return (D) & 83.33 & 77.50 \\
Net Return (D-C) & -5.04 & -7.36 \\
Cost/Liter of milk (C/E) & 28.15 & 28.91 \\
Return/Liter & -1.74 & -2.57 \\
\hline
\end{tabular}

Figures in parentheses indicate the percentages of gross cost.

\section{Maintenance cost and returns from crossbred cow}

The member and non-member maintenance cost for crossbred cow was presented in the Table 3. The per day average gross cost for crossbred cow was found to be higher for members ( $₹ 146.22$ ) as compared to non-members (₹ 142.36). The variable cost accounts $82.88 \%$ and whereas fixed cost was $17.12 \%$ in members as against $82.88 \%$ of variable cost and $18.14 \%$ of fixed cost in non-members. The feed and fodder cost was accounted $67.14 \%$ as followed by labor cost $23.75 \%$ and miscellaneous cost $9.90 \%$ in total variable cost for members. Corresponding figures $68.12 \%$ of feed and fodder cost, $22.92 \%$ of labor cost and $6.60 \%$ of miscellaneous cost for nonmembers. Also, found that per litre cost of milk for member (₹ 20.73) was found to be slightly lesser as compared to non-members ( $₹ 21.10$ ). Because, the members may adopted better management practices to reduce maintenance cost. The net return per litre of milk was found to be higher for members (₹ 3.76) as compared to non-members ( $₹ 3.18)$. The members' milch animals may have good productivity.

Table 4: Average cost and return of crossbred cow for member and non-member groups across different herd size categories (₹ /animal/day)

\begin{tabular}{ccc}
\hline \multirow{2}{*}{ Cost/Return component } & \multicolumn{2}{c}{ Overall } \\
\cline { 2 - 3 } & Member & Non-member \\
\hline Green Fodder (F1) & $25.35(31.16)$ & $25.62(32.26)$ \\
Dry Fodder (F2) & $10.09(12.40)$ & $9.77(12.30)$ \\
Concentrate (F3) & $45.92(56.44)$ & $44.03(55.44)$ \\
Feed \& Fodder cost & $81.37(67.14)$ & $79.42(68.12)$ \\
$(\mathrm{V} 1=\mathrm{F} 1+\mathrm{F} 2+\mathrm{F} 3+\mathrm{G})$ &
\end{tabular}

\begin{tabular}{ccc} 
Labor Cost (V2) & $28.78(23.75)$ & $27.81(22.92)$ \\
Miscellaneous Cost (V3) & $12.11(9.99)$ & $7.67(6.60)$ \\
Total Variable Cost & $121.19(82.88)$ & $116.59(81.86)$ \\
(TVC=V1+V2+V3) & $25.03(17.12)$ & $25.77(18.14)$ \\
Total Fixed Cost (TFC) & $146.22(100.00)$ & $142.36(100.00)$ \\
Gross cost & 5.42 & 5.21 \\
(A=TFC+TVC) & 140.80 & 137.15 \\
Value of Dung (B) & 24.49 & 24.28 \\
Net cost (C=A-B) & & \\
Price of Milk & 6.81 & 6.51 \\
Average milk & & 158.02 \\
production/Animal/ & 166.72 & 20.87 \\
Day(E) & 25.93 & 21.10 \\
Gross Return (D) & 20.73 & 3.18 \\
Net Return (D-C) & 3.76 & \\
Cost/Liter (C/E) & & \\
Return/Liter & & \\
\hline
\end{tabular}

Figures in parentheses indicate the percentages of gross cost.

\section{Maintenance cost and returns from buffalo}

The maintenance cost of for member and nonmembers were shown in the Table 5 . The gross cost per day for buffalo was found to be more ₹ 128.29 for members was more as compared non-members (₹ 124.67 ). In this variable cost accounts $82.95 \%$ and $17.05 \%$ in members as against $81.79 \%$ of variable cost and $18.21 \%$ of fixed cost in non-members. The share of feed and fodder cost was $71.23 \%$ as followed by labour cost $20.51 \%$ and miscellaneous cost $7.41 \%$ in total variable cost for members. Corresponding figures for non-members was $75.12 \%$ of feed and fodder cost, $19.94 \%$ of labor cost and $4.55 \%$ of miscellaneous cost in non-members. The overall per litre cost of milk was found to be slightly higher for non-members (₹ 27.08) as compared to members ( $₹ 26.82$ ). The net return per litre of milk was found to be higher for members (₹ 2.45) as against non-members (₹ 2.02).

Table 5: Average cost and return of buffalo for member and non-member groups across different herd size categories (Kg. /animal/day)

\begin{tabular}{ccc}
\hline \multirow{2}{*}{ Cost/Return component } & \multicolumn{2}{c}{ Overall } \\
\cline { 2 - 3 } & Member & Non-member \\
\hline Green Fodder (F1) & $22.32(29.45)$ & $22.38(29.21)$ \\
Dry Fodder (F2) & $18.45(24.34)$ & $17.17(23.12)$ \\
Concentrate (F3) & $35.03(46.21)$ & $36.52(47.67)$ \\
Feed \& Fodder cost & $75.80(71.23)$ & $76.60(75.12)$ \\
$(\mathrm{V} 1=\mathrm{F} 1+\mathrm{F} 2+\mathrm{F} 3+\mathrm{G})$ &
\end{tabular}




$\begin{array}{ccc}\text { Labor Cost (V2) } & 21.82(20.51) & 20.33(19.94) \\ \text { Miscellaneous Cost (V3) } & 7.89(7.41) & 4.64(4.55) \\ \text { Total Variable Cost } & 106.41(82.95) & 101.97(81.79) \\ \text { (TVC=V1+V2+V3) } & 21.88(17.05) & 22.70(18.21) \\ \text { Total Fixed Cost (TFC) } & 128.29(100.00) & 124.67(100.00) \\ \text { Gross cost (A=TFC+TVC) } & 3.21 & 3.93 \\ \text { Value of Dung (B) } & 124.08 & 120.74 \\ \text { Net cost (C=A-B) } & 29.28 & 29.11 \\ \text { Price of Milk } & & \\ \text { Average milk } & 4.65 & 4.48 \\ \text { production/Animal/ } & & \\ \text { Day(E) } & 135.64 & 129.87 \\ \text { Gross Return (D) } & 11.56 & 9.13 \\ \text { Net Return (D-C) } & 26.82 & 27.08 \\ \text { Cost/Liter (C/E) } & 2.45 & 2.02 \\ \text { Return/Liter } & \end{array}$

Figures in parentheses indicate the percentages of gross cost.

\section{CONCLUSION}

The study concludes that the net returns per milch animal of crossbred cow and buffalo was higher for members as compared to non-members. It may due to good milk productivity of crossbred and buffalo in members as compared to non-members. The net returns for local cow were negative for both members and non-members. It may attribute to low productivity of local cow. So, there is need to upgrade the local cow through suitable government breeding programmers' at district level as well as state level. The cost per liter of milk was lesser in member as compared to non-members in local cow, crossbred cow and buffalo. Because, members undergone the some training programmes like improved dairy management practices like clean milk production, minimization of the feed and fodder wastage etc., so they know better management practices to minimize maintenance cost. Therefore, overall the net returns from dairy farming is higher for members as compared to non-members.

\section{ACKNOWLEDGEMENTS}

First author sincerely acknowledge ICAR-National Dairy Research Institute, for providing financial and infrastructural facilities to carry out this research. I thank my major advisor and advisory committee members for their generous help and valuable suggestions. Also, I express my respect to Head of the Division for her kind co-operation.

\section{REFERENCES}

Devi, G. 2010. Economics of dairy financing through SelfHelp Groups in Jaipur district of Rajasthan. Ph.D. Thesis submitted to National Dairy Research Institute (Deemed University), Karnal, Haryana.

Devi, G., Zala, Y. C. and Jain, D.K. 2014. Micro-finance: A tool for fight against poverty in rural India through self-help group formation, African Journal of Agricultural Science, 9(53): 3864-3878.

Firoze, S.M., Chauhan, A.K., Malhotra, R. and Kadian, K.S. 2011. Factors influencing group repayment performance in Haryana: Application of Tobilt Model, Agricultural Economics Research Review, 24(1): 57-65.

Kumari, B., Malhotra, R. and Chauhan, A.K. 2016. Impact of dairy Co-operatives on women empowerment in Begusarai district of Bihar: A socio-economic analysis, Indian Journal of Dairy Science, 69(4): 487-491.

Ghule, A., Verma, N.K., Chauhan, A.K. and Sawale, P. 2012. An economic analysis of investment pattern, cost of milk production and profitability of commercial dairy farms in Maharashtra, Indian Journal of Dairy Science, 65(4): 329-336.

NABARD (National Bank for Agricultural and Rural Development). 2015. Progress of Self-Help Group-Bank linkage programme. National Bank for Agriculture and Development, Mumbai.

NABARD (National Bank for Agricultural and Rural Development). 2016. Status of microfinance in India: 2015-16. Micro Credit Innovations Department, NABARD, Mumbai.

Sirohi, S., Bardhan, D. and Chand, Prem. 2015. Costs and returns in milk production: Developing standardized methodology and estimates for various production systems. Project report submitted to Department of Animal Husbandry, Dairying and Fisheries, Ministry of Agriculture, Govt. of India, New Delhi. 
